The Canadian Mineralogist

Vol. 45, pp. 1529-1533 (2007)

DOI : $10.3749 /$ canmin.45.6.1529

\title{
THE CRYSTAL STRUCTURE OF TVALCHRELIDZEITE, $\mathrm{Hg}_{3} \mathrm{SbAsS}_{3}$, AND A REVISION OF ITS CHEMICAL FORMULA
}

\author{
HeXiong YANG ${ }^{\S}$, Robert T. DOWNS, Gelu COSTIN AND CARla M. EICHLER \\ Department of Geosciences, University of Arizona, Tucson, Arizona 85721-0077, U.S.A.
}

\begin{abstract}
We have determined the crystal structure of tvalchrelidzeite, $\mathrm{Hg}_{3} \mathrm{SbAsS}_{3}$, for the first time with single-crystal X-ray diffraction. It is monoclinic, with space group $P 2_{1} / n$ and unit-cell parameters $a 11.5526(4), b 4.3852(1), c 15.6373(5) \AA$, $\beta$ 91.845(2) ${ }^{\circ}$, $V 791.79(5) \AA^{3}$. There are eight symmetrically distinct sites in the structure, three occupied by $\mathrm{Hg}$, one by Sb, one by As, and three by $\mathrm{S}$. There is no disorder between $\mathrm{Sb}$ and As. Each $\mathrm{Sb}$ is surrounded by six $\mathrm{S}^{2-}$ anions, with three at distances shorter than $2.51 \AA$ and three at distances longer than $3.20 \AA$. In contrast, each As is coordinated by six $\mathrm{Hg}^{2+}$ cations, with three at distances shorter than $2.51 \AA$ and three at distances longer than $3.31 \AA$. All three independent $\mathrm{Hg}$ ions are situated in considerably distorted octahedral sites, with two opposite bonds (one $\mathrm{Hg}-\mathrm{S}$ and one $\mathrm{Hg}-\mathrm{As}$ ) shorter than $2.51 \AA$ and four equatorial bonds longer than $2.98 \AA$. The structure of tvalchrelidzeite can be viewed as a sequence of sheets parallel to (101). These sheets are composed of $\left[\mathrm{Hg}_{6} \mathrm{Sb}_{2} \mathrm{As}_{2} \mathrm{~S}_{6}\right]$ ribbon-like units (extending along the $b$ axis) linked together by the short $\mathrm{Hg} 1-\mathrm{As}$ bonds $(2.494 \AA$ ). The linkage between sheets is achieved through the weak $\mathrm{Hg}-\mathrm{S}(>3.0 \AA)$ and $\mathrm{Sb}-\mathrm{S}(>3.2 \AA)$ bonds, accounting for the observed perfect cleavage in one direction. Tvalchrelidzeite represents one of very few sulfosalt minerals that contain both $\mathrm{Sb}$ and As, with the latter behaving as an anion.
\end{abstract}

Keywords: tvalchrelidzeite, mercury-bearing sulfosalt, crystal structure.

\section{SOMMAIRE}

Nous avons établi la structure cristalline de la tvalchrelidzéite, $\mathrm{Hg}_{3} \mathrm{SbAsS}_{3}$, pour la première fois par diffraction $\mathrm{X}$ sur monocristal. Il s'agit d'un minéral monoclinique, groupe spatial $P 2_{1} / n$, ayant les paramètres réticulaires $a 11.5526(4), b 4.3852(1), c$ 15.6373(5) $\AA, \beta$ 91.845(2) ${ }^{\circ}, V 791.79(5) \AA^{3}$. La structure contient huit sites symétriquement distincts, trois sites contenant $\mathrm{Hg}$, un contenant $\mathrm{Sb}$, un autre As, et trois contenant S. Il n'y a aucun désordre entre Sb et As. Chaque atome de Sb est entouré par six anions $\mathrm{S}^{2-}$, trois atomes à une courte distance, inférieure à $2.51 \AA$, et trois à une distance supérieure à $3.20 \AA$. En revanche, chaque atome de As est coordonné à six atomes de $\mathrm{Hg}^{2+}$, trois de ceux-ci à une distance inférieure à $2.51 \AA$ et trois à une distance supérieure à 3.31 Å. Chacun des ions indépendants de Hg occupe un site octaédrique passablement difforme, avec deux liaisons opposées (une liaison $\mathrm{Hg}-\mathrm{S}$ et une liaison $\mathrm{Hg}-\mathrm{As}$ ) inférieures à $2.51 \AA$ A , et quatre liaisons équatoriales dépassant $2.98 \AA$. On peut considérer la structure de la tvalchrelidzéite comme une séquence de feuillets parallèles à (101). Ces feuillets sont composés de rubans $\left[\mathrm{Hg}_{6} \mathrm{Sb}_{2} \mathrm{As}_{2} \mathrm{~S}_{6}\right]$ alignés le long de l'axe $b$, interconnectés par les liaisons courtes $\mathrm{Hg} 1-\mathrm{As}(2.494 \AA)$. Les connexions interfeuillets sont assurées par les liaisons relativement faibles $\mathrm{Hg}-\mathrm{S}(>3.0 \AA)$ et $\mathrm{Sb}-\mathrm{S}(>3.2 \AA)$, ce qui rend compte du clivage parfait dans une direction. La tvalchrelidzéite représente un cas rare d'un sulfosel contenant à la fois Sb et As, ce dernier agissant comme anion.

Mots-clés: tvalchrelidzéite, sulfosel de mercure, structure cristalline.

\section{INTRODUCTION}

Among many known As- and Sb-containing sulfosalt minerals, a few contain mercury as a specific constituent (Strunz \& Nickel 2001), including tvalchrelidzeite $\mathrm{Hg}_{3} \mathrm{SbAsS}_{3}$, christite $\mathrm{TlHgAsS}_{3}$, laffittite $\mathrm{AgHgAsS}_{3}$, simonite $\mathrm{TlHgAs}_{3} \mathrm{~S}_{6}$, routhierite $\mathrm{CuHg}_{2}$ $\mathrm{TlAs}_{2} \mathrm{~S}_{6}$, vaughanite $\mathrm{HgTlSb}_{4} \mathrm{~S}_{7}$, livingstonite $\mathrm{HgSb}_{4} \mathrm{~S}_{8}$, aktashite $\mathrm{Cu}_{6} \mathrm{Hg}_{3} \mathrm{As}_{4} \mathrm{~S}_{12}$, gruzdevite $\mathrm{Cu}_{6} \mathrm{Hg}_{3} \mathrm{Sb}_{4} \mathrm{~S}_{12}$, vrbaite $\mathrm{Hg}_{3} \mathrm{Tl}_{4} \mathrm{As}_{8} \mathrm{Sb}_{2} \mathrm{~S}_{20}$, and fettelite $\mathrm{Ag}_{24} \mathrm{HgAs}_{5} \mathrm{~S}_{20}$. Tvalchrelidzeite was first discovered in the Gomi deposit, Caucasus Mountains, Georgia, and described by Gruzdev et al. (1975) with a chemical formula of $\mathrm{Hg}_{12}(\mathrm{Sb}, \mathrm{As})_{8} \mathrm{~S}_{15}$ and a monoclinic unit-cell: $a$ 11.51(4), $b$ 4.39(2), c 14.62(6) $\AA$, and $\beta$ 92.14 ${ }^{\circ}$. Pobedimskaya et al. (1980) conducted a structural study on tvalchrelidzeite and obtained as crystal-chemical formula $\mathrm{Hg}_{10}(\mathrm{Sb}, \mathrm{As})_{8} \mathrm{~S}_{16}$, with a discrepancy $R$-factor of $9.0 \%$

§ E-mail address: hyang@u.arizona.edu 
on the basis of triclinic $P 1$ symmetry and unit-cell parameters $a$ 4.391(1), $b$ 11.573(9), $c$ 15.667(7) $\AA, \alpha$ 88.17(5), $\beta$ 90.01(3), $\gamma$ 89.98(5) ${ }^{\circ}$. However, they did not report any coordinates of atoms for the mineral. In a further examination of the composition of tvalchrelidzeite, Krapiva et al. (1986) suggested that this mineral may be a solid solution between the endmembers $\mathrm{Hg}_{3} \mathrm{As}_{2} \mathrm{~S}_{3}$ and $\mathrm{Hg}_{3} \mathrm{Sb}_{2} \mathrm{~S}_{3}$, and its chemical formula should be $\mathrm{Hg}_{3}(\mathrm{As}, \mathrm{Sb})_{2} \mathrm{~S}_{3}$, rather than that proposed by Gruzdev et al. (1975) or Pobedimskaya et al. (1980). In this paper, we report a crystal-structure determination of tvalchrelidzeite, and show that this mineral possesses monoclinic $P 2_{1} / n$ symmetry with $\mathrm{Sb}$ and As occupying distinct sites, resulting in the crystalchemical formula, $\mathrm{Hg}_{3}{ }^{2+} \mathrm{As}^{3-} \mathrm{Sb}^{3+} \mathrm{S}_{3}$.

\section{EXPERIMENTAL PROCEDURES}

The tvalchrelidzeite crystal used in this study is from the type locality, the Gomi deposit, Georgia, and is in the collection of the RRUFF project (deposition No. R061128; http://rruff.info). The chemical composition was determined with a CAMECA SX50 electron microprobe (http://rruff.info). The average composition (15 point analyses), normalized on the basis of $3 \mathrm{~S}$ atoms, yielded a formula of $\mathrm{H}_{3.03 \pm 0.03} \mathrm{Sb}_{1.03 \pm 0.02} \mathrm{As}_{1.00 \pm 0.04} \mathrm{~S}_{3}$. Thus, in the following determination and refinements

\begin{tabular}{|c|c|c|c|}
\hline $\begin{array}{l}\text { Structural formula } \\
\text { Crystal size }\left(\mathrm{mm}^{3}\right)\end{array}$ & $\begin{array}{l}\mathrm{Hg}_{3} \mathrm{SbAsS}_{3} \\
0.07 \times 0.07 \times 0.06\end{array}$ & $\begin{array}{l}\text { Space group } \\
a(\bar{A})\end{array}$ & $\begin{array}{l}P 2_{1} / n(\text { no. } 14) \\
11.5526(4)\end{array}$ \\
\hline$\rho_{\text {cail }}\left(\mathrm{g} / \mathrm{cm}^{3}\right)$ & 7.505 & $b(\AA)$ & $4.3852(1)$ \\
\hline$\lambda(A)$ & 0.71069 & $c(\AA)$ & $15.6373(5)$ \\
\hline$\mu\left(\mathrm{mm}^{-1}\right)$ & 66.20 & $\beta\left(^{\circ}\right)$ & $91.845(2)$ \\
\hline$\theta$ range for data collection & 2.23 to 35.50 & $V\left(\AA^{3}\right)$ & $\begin{array}{l}791.78(5) \\
4\end{array}$ \\
\hline \multicolumn{2}{|c|}{ Number of reflections collected } & 13772 & \\
\hline \multicolumn{2}{|c|}{ Number of independent reflections } & 3464 & \\
\hline \multicolumn{2}{|c|}{ Number of refiections with $I>2 \sigma(l)$} & 2720 & \\
\hline \multicolumn{2}{|c|}{ Number of parameters refined } & 74 & \\
\hline \multicolumn{2}{|l|}{$R$ (int) } & 0.045 & \\
\hline \multicolumn{2}{|l|}{ Final $R$ factors $[/>2 \sigma(l)]$} & \multicolumn{2}{|c|}{$R_{1}=0.031, w R_{2}=0.071$} \\
\hline \multirow{2}{*}{\multicolumn{2}{|c|}{ Final $R$ factors (all data) }} & \multirow{2}{*}{\multicolumn{2}{|c|}{$R_{1}=0.048, w R_{2}=0.097$}} \\
\hline & & & \\
\hline
\end{tabular}

of the structure, we assumed an ideal stoichiometry, $\mathrm{Hg}_{3} \mathrm{SbAsS}_{3}$.

On the basis of an optical examination and profiles of X-ray-diffraction peaks, a nearly cubic crystal was selected and mounted on a Bruker X8 APEX2 CCD $\mathrm{X}$-ray diffractometer equipped with graphite-monochromatized $\mathrm{MoK} \alpha$ radiation. X-ray-diffraction data were collected with frame widths of $0.5^{\circ}$ in $\omega$ and $30 \mathrm{~s}$ counting time per frame. All reflections were collected and indexed on the basis of a monoclinic unit-cell (Table 1). The intensity data were corrected for X-ray absorption using the Bruker program SAINT. Observed systematic absences of reflections indicate the unique space-group $P 2_{1} / n$. The crystal structure was solved and refined with SHELX97 (Sheldrick 1997). The positions of all atoms were refined with anisotropic displacement parameters. The Sb and As atoms occupy two distinct sites; no disorder between them was detected. Final coordinates and anisotropic displacement parameters of the atoms are listed in Table 2, and selected bonddistances in Table 3. A table of structure factors is available from the Depository of Unpublished Data on the MAC web site [document Tvalchredlidzeite CM45_1529].

\section{RESULTS AND DISCUSSION}

There are eight symmetrically nonequivalent atomic sites (all on general positions) in the structure of tvalchrelidzeite, three being occupied by $\mathrm{Hg}$, one by $\mathrm{Sb}$, one by As, and three by S. The most notable structural feature is that there is no disorder or mixing between $\mathrm{Sb}$ and As. The $\mathrm{Sb}$ atom behaves as a cation and is surrounded by six $\mathrm{S}^{2-}$ ions, with three at distances less than $2.51 \AA$ and three at distances greater than $3.20 \AA$ (Table 3, Fig. 1). In contrast, As behaves as an anion and is coordinated by six $\mathrm{Hg}^{2+}$ ions, with three at distances less than $2.51 \AA$ and three at distances greater than $3.31 \AA$ (Fig. 1). Such coordination of $\mathrm{Sb}$ and $\mathrm{As}$ in tvalchrelidzeite is observed in many other sulfosalts (see Makovicky 1997, 2006 for reviews). The three shorter $\mathrm{Sb}-\mathrm{S}$ and $\mathrm{As}-\mathrm{Hg}$ bonds give rise to $\mathrm{SbS}_{3}$ and $\mathrm{AsHg}_{3}$ trigonal pyramidal configurations, with $\mathrm{Sb}$ and $\mathrm{As}$ at

TABLE 2. COORDINATES AND DISPLACEMENT PARAMETERS $\left(\AA^{2}\right)$ OF ATOMS IN TVALCHRELIDZEITE

\begin{tabular}{|c|c|c|c|c|c|c|c|c|c|c|}
\hline Atom & $x$ & $y$ & $z$ & $U_{\text {eq }}$ & $U_{11}$ & $U_{12}$ & $U_{13}$ & $U_{22}$ & $U_{23}$ & $U_{33}$ \\
\hline $\mathrm{Hg} 1$ & $0.61911(3)$ & $0.36405(11)$ & $0.31860(3)$ & $0.0224(1)$ & $0.0142(2)$ & $0.0018(1)$ & $-0.0016(1)$ & $0.0288(2)$ & $-0.0030(1)$ & $0.0240(2)$ \\
\hline $\mathrm{Hg} 2$ & $0.36925(3)$ & $0.72983(9)$ & $0.42456(3)$ & $0.0209(1)$ & $0.0213(2)$ & $0.0022(1)$ & $0.0032(1)$ & $0.0232(2)$ & $-0.0054(1)$ & $0.0185(2)$ \\
\hline $\mathrm{Hg} 3$ & $0.39099(4)$ & $0.71836(10)$ & $0.18764(2)$ & $0.0221(1)$ & $0.0274(2)$ & $0.0020(1)$ & $-0.0022(1)$ & $0.0237(2)$ & $0.0052(1)$ & $0.0149(2)$ \\
\hline $\mathrm{Sb}$ & $0.85759(5)$ & $0.81322(15)$ & $0.44887(4)$ & $0.0135(1)$ & $0.0133(2)$ & $-0.0001(2)$ & $-0.0006(2)$ & $0.0143(3)$ & $-0.0004(2)$ & $0.0129(3)$ \\
\hline As & $0.4033(1)$ & $0.3522(2)$ & $0.3077(1)$ & $0.0145(2)$ & $0.0152(4)$ & $-0.0007(3)$ & $0.0002(3)$ & $0.0139(4)$ & $-0.0001(3)$ & $0.0143(4)$ \\
\hline s1 & $0.8268(2)$ & $0.4521(6)$ & $0.3312(1)$ & $0.0162(4)$ & $0.0151(9)$ & $0.0001(8)$ & $0.0007(7)$ & $0.0210(11)$ & $-0.0019(8)$ & $0.0124(10)$ \\
\hline S2 & $0.3534(2)$ & $0.1061(6)$ & $0.5368(1)$ & $0.0162(4)$ & $0.0144(9)$ & $0.0005(8)$ & $0.0008(8)$ & $0.0175(10)$ & $-0.0020(9)$ & $0.0167(10)$ \\
\hline s3 & $0.3805(2)$ & $0.0639(6)$ & $0.0689(1)$ & $0.0156(4)$ & $0.0165(10)$ & $-0.0018(8)$ & $-0.0005(7)$ & $0.0178(10)$ & $0.0013(8)$ & $0.0123(9)$ \\
\hline
\end{tabular}



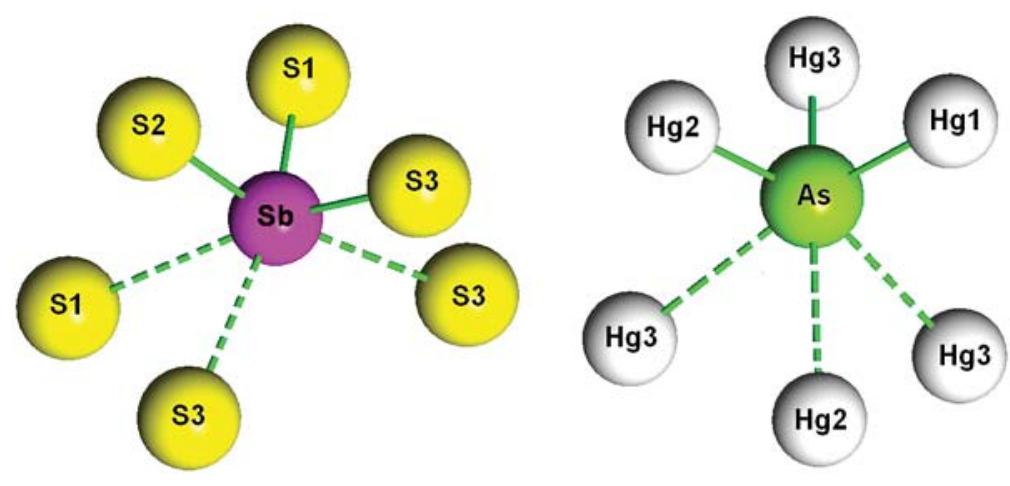

FIG. 1. Atomic coordinations around $\mathrm{Sb}$ and $\mathrm{As}$ in tvalchrelidzeite. The bonds shorter than $2.51 \AA$ are shown with solid lines, and those longer than $3.0 \AA$, with broken lines.

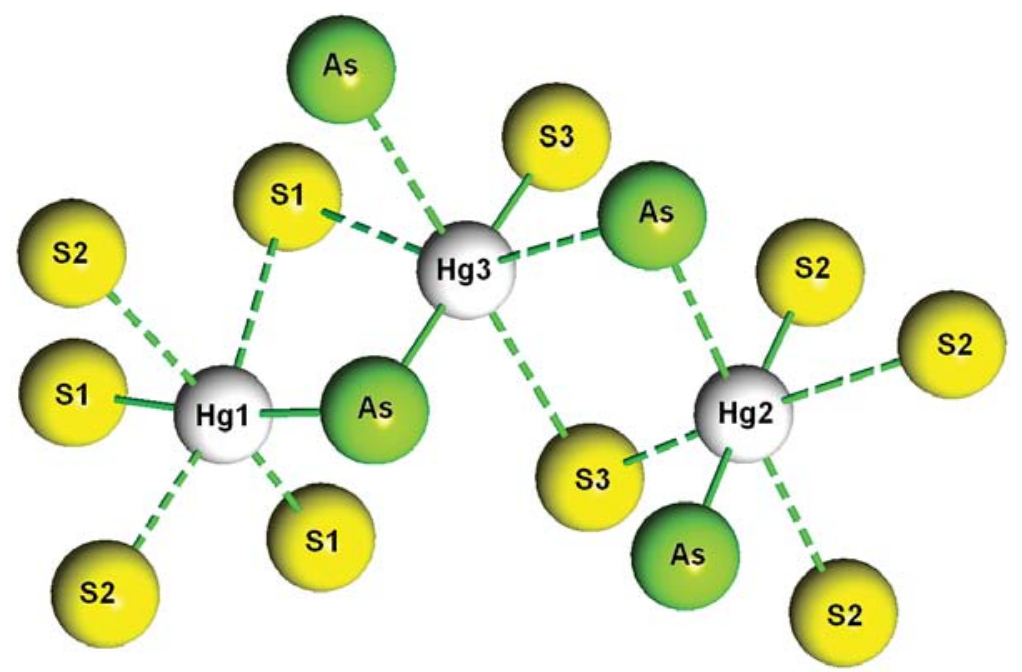

Fig. 2. Coordination environments around three $\mathrm{Hg}^{2+}$ cations in tvalchrelidzeite. The bonds shorter than $2.51 \AA$ are shown with solid lines, and those longer than $2.98 \AA$, with broken lines.

the respective vertices, whereas the three longer $\mathrm{Sb}-\mathrm{S}$ and $\mathrm{As}-\mathrm{Hg}$ bonds are primarily a consequence of the lone-electron-pair activities of $\mathrm{Sb}$ and As ions. Using the parameters given by Brese \& O'Keeffe (1991), the bond-valence sums calculated for $\mathrm{Sb}$ and As are 2.98 and 3.08 valence units $(v u)$, respectively, from the three shorter bonds, and 3.30 and $3.37 v u$ from all six bonds. The three independent $\mathrm{Hg}$ ions are situated in the considerably distorted octahedral sites with two opposite bonds (one $\mathrm{Hg}-\mathrm{S}$ and one $\mathrm{Hg}-\mathrm{As}$ ) shorter than 2.51 $\AA$ and four equatorial bonds longer than $2.98 \AA$ (Table 3 , Fig. 2). Such flattened octahedral coordination is characteristic of the structural chemistry of $\mathrm{Hg}$ and has been observed in livingstonite, $\mathrm{HgSb}_{4} \mathrm{~S}_{8}$ (Srikrishnan \& Nowacki 1975), vrbaite (Ohmasa \& Nowacki 1971), radtkeite, $\mathrm{Hg}_{3} \mathrm{~S}_{2} \mathrm{ClI}$ (Pervukhina et al. 2004), and other $\mathrm{Hg}$-bearing compounds. The angles between the two short $\mathrm{Hg}-\mathrm{S}$ and $\mathrm{Hg}-\mathrm{As}$ bonds are 172.02(7), 175.19(6), and $178.61(7)^{\circ}$ for the $\mathrm{Hg} 1, \mathrm{Hg} 2$, and $\mathrm{Hg} 3$ octahedra, respectively. The principal difference among these three octahedra lies in the ratio of $\mathrm{S}$ versus As atoms bonded to each $\mathrm{Hg}$. Specifically, this ratio is $5: 1,4: 2$, and $3: 3$ for $\mathrm{Hg} 1, \mathrm{Hg} 2$, and $\mathrm{Hg} 3$, respectively. Associated with this difference is the degree of the octahedral distortion, as 


\begin{tabular}{lllll}
\multicolumn{5}{c}{ TABLE 3. INTERATOMIC DISTANCES (A) IN TVALCHRELIDZEITE } \\
\hline
\end{tabular}

measured by the octahedral quadratic elongation (OQE) (Robinson et al. 1971), which is $1.058,1.068$, and 1.075 for $\mathrm{Hg} 1, \mathrm{Hg} 2$, and $\mathrm{Hg} 3$, respectively.

Three symmetrically distinct $\mathrm{S}$ atoms (S1, S2, and S3) display a similar $(2+4)$ configuration: they all have two bonds (one $\mathrm{S}-\mathrm{Hg}$ and one $\mathrm{S}-\mathrm{Sb}$ ) shorter than 2.51 $\AA$ and four bonds longer than $2.98 \AA$ (Table 3). Furthermore, the angle between the two short bonds only varies from $99.45(9)^{\circ}$ for $\mathrm{Hg} 3-\mathrm{S} 3-\mathrm{Sb}$ to $106.44(9)^{\circ}$ for $\mathrm{Hg} 1-\mathrm{S} 1-\mathrm{Sb}$. Nonetheless, three $\mathrm{S}$ atoms are surrounded by the different ratios of $\mathrm{Hg}$ and $\mathrm{Sb}$ cations. They are 4:2, 5:1, and 3:3 for $S 1, S 2$, and S3, respectively.

Viewed along the $b$ axis (Fig. 3), the crystal structure of tvalchrelidzeite can be regarded as a sequence of sheets parallel to (101). These sheets are made of $\left[\mathrm{Hg}_{6} \mathrm{Sb}_{2} \mathrm{As}_{2} \mathrm{~S}_{6}\right]$ ribbon-like units (extending along the $b$ axis) that are linked together by the short $\mathrm{Hg} 1-$ As bonds $(2.494 \AA)$. The linkage between sheets is achieved by the weak $\mathrm{Hg}-\mathrm{S}(>3.0 \AA)$ and $\mathrm{Sb}-\mathrm{S}(>3.2 \AA)$ bonds, which accounts well for the observed perfect cleavage in one direction (Gruzdev et al. 1975). It is also evident from Figure 3 that the lone-electron-pair activity of the As ions is confined within the $\left[\mathrm{Hg}_{6} \mathrm{Sb}_{2} \mathrm{As}_{2} \mathrm{~S}_{6}\right]$ ribbon-

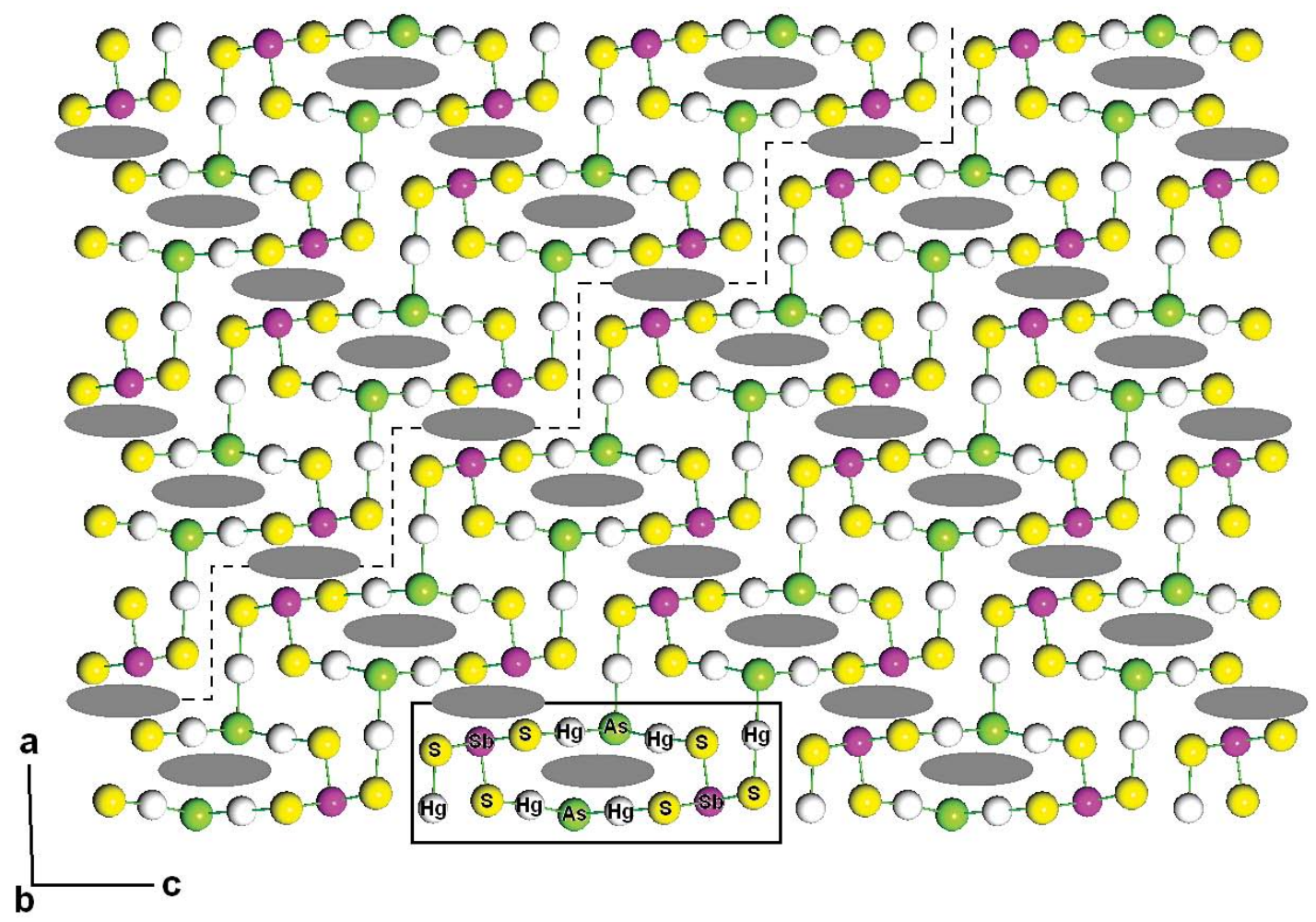

FIG. 3. Crystal structure of tvalchrelidzeite viewed along the $b$ axis. Solid lines represent bonds within $\left.2.98 \AA . \mathrm{A}^{2} \mathrm{Hg}_{6} \mathrm{Sb}_{2} \mathrm{As}_{2} \mathrm{~S}_{6}\right]$ ribbon-like unit is outlined with a rectangular box. The shaded ovals represent lone-electron-pair micelles formed by Sb and As ions. The broken zigzag line shows the orientation of the perfect cleavage. 
like units, whereas that of the $\mathrm{Sb}$ ions takes place between sheets.

It is intriguing to note that $\mathrm{Sb}$ and As are observed to act as trivalent cations in most sulfosalts containing both of them (e.g., Makovicky 1997, 2006, Strunz \& Nickel 2001), and they can even substitute for one another completely in some cases, such as in twinnite, $\mathrm{Pb}_{2}(\mathrm{Sb}, \mathrm{As})_{2} \mathrm{~S}_{4}$, veenite, $\mathrm{Pb}_{2}(\mathrm{Sb}, \mathrm{As})_{2} \mathrm{~S}_{5}$, gillulyite, $\mathrm{Tl}_{2}(\mathrm{As}, \mathrm{Sb})_{8} \mathrm{~S}_{13}$, geocronite, $\mathrm{Pb}_{5}(\mathrm{Sb}, \mathrm{As})_{2} \mathrm{~S}_{8}$, rebulite, $\mathrm{Tl}_{5} \mathrm{Sb}_{4.45} \mathrm{As}_{8.55} \mathrm{~S}_{22}$, and getchellite, $\mathrm{AsSbS}_{3}$. The only exception found thus far is pääkkönenite, $\mathrm{Sb}_{2} \mathrm{AsS}_{2}$, in which As occupies a vertex of a trigonal pyramid and is bonded to itself plus two Sb atoms, with an As-As bond length of $2.466 \AA$ (Bonazzi et al. 1995). The calculated formal charge for the As-As pair in pääkkönenite is -3.7. According to Bonazzi et al. (1995), the As ions in pääkkönenite play a role analogous to that of the $S_{\text {II }}$ ions in stibnite, $\mathrm{Sb}_{2} \mathrm{~S}_{3}$, in which $\mathrm{S}_{\mathrm{II}}$ is also bonded to itself to form an S-S pair (Bayliss \& Nowacki 1972). Tvalchrelidzeite, therefore, provides a second example among sulfosalts that contain both $\mathrm{Sb}$ and $\mathrm{As}$, with the latter behaving as an anion.

\section{ACKNOWLEDGEMENTS}

We gratefully acknowledge the support of this study from the RRUFF project and National Science Foundation (EAR-0609906). The sample was donated to the project by Michael Scott. The constructive comments and suggestions from L. Bindi and N.V. Pervukhina for the improvement of our manuscript are greatly appreciated.

\section{REFERENCES}

BAYLISS, P. \& NOWACKI, W. (1972): Refinement of the crystal structure of stibnite, $\mathrm{Sb}_{2} \mathrm{~S}_{3}$. Z. Kristallogr. 135, 308-315.

Bonazzi, P., Borrini, D., Mazzi, F. \& Olmi, F. (1995): Crystal structure and twinning of $\mathrm{Sb}_{2} \mathrm{AsS}_{2}$, the synthetic analogue of pääkkönenite. Am. Mineral. 80, 1054-1058.

BRESE, N.E. \& O'KeEFFe, M. (1991): Bond-valence parameters for solids. Acta Crystallogr. B47, 192-197.

Gruzdev, V.S., Mchedlishvili, N.M., Terekhova, G.A., Tsertsvadze, Z.Y., Chernitsova, N.M. \& Shumkova,
N.G. (1975): Tvalchrelidzeite, $\mathrm{Hg}_{12}(\mathrm{Sb}, \mathrm{As})_{8} \mathrm{~S}_{15}$, a new mineral from the Gomi arsenic - antimony - mercury deposit, Caucasus. Dokl. Akad. Nauk SSSR 225, 911-913 (in Russ.).

Krapiva, L.Ya, Stepanov, V.I., Nechelyustov, G.N. \& Bolgin, V.Y. (1986): New data on tvalchrelidzeite $\mathrm{Hg}_{12}(\mathrm{As}, \mathrm{Sb})_{8} \mathrm{~S}_{12}$. Dokl. Akad. Nauk SSSR 290, 1208-1212 (in Russ.).

MAKOvickY, E. (1997): Modular crystal chemistry of sulphosalts and other complex sulphides. In Modular Aspects of Minerals (S. Merlino, ed.). Eur. Mineral. Union, Notes in Mineralogy 1, 237-271.

MAKOvicky, E. (2006): Crystal structures of sulfides and other chalcogenides. In Sulfide Mineralogy and Geochemistry (D.J. Vaughan, ed.). Rev. Mineral. Geochem. 61, 7-125.

OHMASA, M. \& Nowacki, W. (1971): The crystal structure of vrbaite $\mathrm{Hg}_{3} \mathrm{Tl}_{4} \mathrm{As}_{8} \mathrm{Sb}_{2} \mathrm{~S}_{20}$. Z. Kristallogr. 134, 360-380.

Pervukhina, N.V., Vasil'ev, V.I., Naumov, D.Yu., Borisov, S.V. \& MAGARILL, S.A. (2004): The crystal structure of synthetic radtkeite, $\mathrm{Hg}_{3} \mathrm{~S}_{2}$ CII. Can. Mineral. 42, 87-94.

Pobedimskaya, Y.A., Belov, N.V., Kaplunnik, L.N. \& Petrova, I.V. (1980): The crystal chemistry of the series of $\mathrm{Pb}$ and $\mathrm{Hg}$ sulfosalts. In Sulfosalts, Platinum Minerals, and Ore Microscopy. Nauka Press, Moscow, Russia (49-58; in Russ. with English abstr.).

Robinson, K., Gibbs, G.V. \& RibBe, P.H. (1971): Quadratic elongation, a quantitative measure of distortion in coordination polyhedra. Science 172, 567-570.

SHELDRICK, G.M. (1997): SHELX97 (release 97-2). University of Göttingen, Göttingen, Germany.

SRIKRISHNAN, T. \& NOWACKI, W. (1975): A redetermination of the crystal structure of livingstonite, $\mathrm{HgSb}_{4} \mathrm{~S}_{8}$. Z. Kristallogr. 141, 174-192.

StrunZ, H. \& Nickel, E.H. (2001): Strunz Mineralogical Tables. Chemical-Structural Classification System $\left(9^{\text {th }}\right.$ ed.). Schweizerbart'sche, Stuttgart, Germany.

Received February 21, 2007, revised manuscript accepted June 14, 2007. 